\title{
Pemanfaatan Tenaga Surya Pada Photovoltaic Jenis Polycristaline Untuk Catu Daya Tanaman Hidroponik
}

\author{
Samsurizal ${ }^{1}$; Max Teja $\mathrm{Aji}^{2}$; Kartika Tresya $\mathbf{M}^{3}$ \\ ${ }^{1,2,3}$ Teknik Elektro, Institut Teknologi PLN \\ ${ }^{1}$ samsurizal@itpln.ac.id
}

\begin{abstract}
The use of solar energy today as an alternative energy source continues to be used not only in large scale but also utilized on small scale. The use of solar power as a renewable energy source by converting solar energy into electrical energy, utilizing this technology one of them on technology using hydroponic plant systems. In hydroponic pump system used to consume water and nutrients are usually sourced electricity PLN. With the availability of abundant energy sources certainly help reduce electricity consumption from PLN. The design is done on this research by utilizing solar energy as a power supply to turn on the pumps as well as to drain water and plant nutrients running well. The burden used in this study was 20Watt, to supply the load needs of a PLTS fitted with polycristaline type. The highest irradiation at 12.00 is $666 \mathrm{~W} / \mathrm{M}^{2}$ which means that at that time the energy is generated maximally. In the design used with the battery capacity using the VRLA Deep Cycle JS12-12 battery type; $12 \mathrm{~V} 12 \mathrm{Ah}$ generated and stored electrical energy can turn the 5-6 hour pump on.
\end{abstract}

Keywords: Alternative Energy, Energy Conversion, PLTS, Hydroponic

\begin{abstract}
Abstrak
Pengunaan energi matahari saat ini sebagai sumber energi alternatif terus digunakan tidak hanya dalam skala besar tapi juga dimanfaatkan pada skala kecil. Penggunaan Tenaga Surya sebagai sumber energi terbarukan dengan mengkonversi energi matahari menjadi energi listrik, pemanfaatan teknologi ini salah satunya pada teknologi menggunakan sistem tanaman hidroponik. Pada sistem hidroponik pompa yang digunakan untuk mengaliri air dan nutrisi biasanya bersumber listrik PLN. Dengan tersedianya sumber energi yang melimpah tentunya membantu mengurangi konsumsi listrik dari PLN. Perancangan yang dilakukan pada penelitian ini dengan memanfaatkan energi surya sebagai catu daya untuk menghidupkan pompa serta untuk mengalirkan air dan nutrisi tanaman berjalan dengan baik. Beban yang digunakan dalam penelitian ini sebesar 20Watt, untuk mensuplai kebutuhan beban tersebut dipasang PLTS dengan jenis polycristaline. Iradiasi tertinggi pada pukul 12.00 sebesar 666 W/M ${ }^{2}$ yang berarti pada waktu tersebut energi yang dihasilkan maksimal. Pada perancangan yang digunakan dengan kapasitas baterai menggunakan tipe baterai VRLA Deep Cycle JS12-12; $12 \mathrm{~V}$ 12Ah energi listrik yang dihasilkan dan disimpan dapat menghidupkan pompa 5-6 jam.
\end{abstract}

Kata Kunci: Energi Alternatif, Konversi Energi, PLTS, Hidroponik 


\section{PENDAHULUAN}

Saat ini teknologi pertanian dengan media ruang atau wilayah yang sempit, kecil dan memiliki lahan terbatas menjadi hal yang banyak digunakan pada masyarakat. Dengan media tanam air yang menggunakan pompa mengalir terus. Penggunaan pompa air tentunya membutuhkan listrik sebagai sumber catu daya, selama ini sumber yang digunakan bersumber dari PLN. Tersedianya energi terbarukan yang melimpah, tentunya menjadi hal yang bisa digunakan untuk menerapkan teknologi ini. Sumber energi listrik merupakan kebutuhan primer yang dalam mendorong aktivitas kehidupan umat manusia. Energi terbarukan mempunyai sifat terbarukan dan berkesinambungan salah satunya bersumber dari energi matahari sebagai sumber energi terbarukan. Kompenan utama dari energi ini terletak pada sel surya (cell photovoltaic). Energi surya biasanya pemanfaatannya di daerah yang paparan radiasi matahari yang cukup tinggi serta daerah yang belum terjangkau dan adanya listrik PLN. Sumber energi matahari yang banyak dan berlimpah tentunya menjadi hal yang bisa dimanfaatkan, pemanfaatan energi terbarukan yaitu dengan pemanfaatan sinar matahari tersebut sangat bagus dikarenakan letak geografis Indonesia yang berada di daerah khatulistiwa memiliki potensi penyinaran yang cukup memadai. Indonesia ialah negara yang berada di garis khatulistiwa serta mempunyai tingkat paparan radiasi matahari rata - rata yang relatif tinggi sebesar 4,5 $\mathrm{kWh} / \mathrm{m}^{2} /$ hari [1]. Tentunya dari letak geografis tersebut digunakan sebagai dasar utama yang menguntungkan pemanfaatan pembangkitan listrik berbasis energi matahari. Unsur utama dari sistem photovoltaic ialah sel surya yang berfungsi untuk merubah dan menyerap energi cahaya matahari menjadi energi listrik siap pakai [2].

Tanaman hidroponik memerlukan catu daya sebagai sumber listrik dalam menyalurkan air pada tanaman, pemanfaatan energi terbarukan dalam konversi energi pada tanaman hidroponik menjadi satu hal yang dapat diterapkan [3]. Integritas konversi energi terbarukan sebagai alternative pemanfaatan sumber energi. Media tanam dengan sistem hidroponik dapat dikelompokkan ke dalam dua kelompok, pertama dengan kultur air yang tidak menggunakan media pendukung lain untuk perakaran tanaman serta kultur substrat maupun agregat yang menggunakan media padat untuk mendukung perakaran tanaman [4].

Penelitian sebelumnya yang berjudul Automatic control of drip irrigation on hydroponic agriculture mencoba mengontrol tanaman hidroponik sebagai pengairan serta monitoring, namun belum memanfaatkan energi terbarukan sebagai sumber energi listrik [5]. Penelitian lain yang dilakukan jatimko dalam tulisannya bagaimana memanfaatkan energi terbarukan sebagai catu daya, namun dalam penelitiannya pemanfaatan yang di gunakan untuk penerangan pada lampu LED [6]. Pada artikel yang diterbitkan oleh jurnal setrum menggunakan photovoltaic jenis Monocristalline perancangan dilakukan untuk mengetahui Sudut radiasi yang optimum. Diperoleh hasil rata-rata paparan radiasi $517 \mathrm{~W} / \mathrm{M}^{2}$ dan rata-rata arus yang dihasilkan sebesar $1.58 \mathrm{~A}$ dengan sudut panel terhadap matahari sebesar 25-35 [7]. Sedangkan pada penelitian berjudul Characteristics of Temperature Changes Measurement on Photovoltaic Surfaces Against Quality of Output Current on Solar Power Plants, menghasilkan arus optimal adalah pada 1,92 Ampere, suhu optimum pada 37,4 ${ }^{\circ} \mathrm{C}$, dan nilai tukar tertinggi adalah pada 2,08 Ampere sedangkan suhu pada permukaan sel surya adalah pada $37,4^{\circ} \mathrm{C}$. Dengan analisis persamaan regresi matematis yaitu persamaan statistik regresi kuadrat, dapat diketahui bahwa karakteristik sel surya memiliki tenaga kerja yang efisien adalah sekitar $37,4^{\circ} \mathrm{C}$ [8]. Penelitian lain juga merancang sistem hidroponik otomatis pasang surut yang dapat menghidupkan / mematikan pompa berdasarkan kadar air menggunakan mikrokontroler Nilai titik pengaturan yang diperoleh untuk mengontrol kadar air untuk menghidupkan pompa adalah $<34,95 \%$ dan mematikan pompa adalah $>69,83 \%$. Uji budidaya menggunakan cabai cabai 


\section{Energi dan Kelistrikan: Jurnal Ilmiah}

Vol. 13, No. 1, Januari - Juni 2021, P-ISSN 1979-0783, E-ISSN 2655-5042

https://doi.org/10.33322/energi.v13i1.984

menghasilkan sistem hidroponik surut dan pasang surut secara otomatis lebih baik daripada sistem manual satu, persilangan tinggi tanaman dan jumlah daun [9].

Photovoltaic merupakan suatu divais yang mampu mengkonversi energi foton cahaya menjadi energi listrik secara langsung. Prosesnya disederhanakan dari pembangkitan listrik di dalam sel surya. Jika sebuah beban lampu dihubungkan secara seri ataupun paralel dengan rangkaian luar yang menghubungkan kontak positif dan negative sel. Foton-foton cahaya yang memiliki energi berbedabeda masuk dan terserap melalui lapisan atas (bahan semikonduktor tipe-n) menuju bahan semikonduktor tipe-p yang lebih tebal pada kedalaman yang berbeda dari permukaan sel [10]. Letak kemiringan panel surya diatur yang paling tepat agar mendapatkan paparan radiasi matahari yang cukup tinggi, besarnya radiasi matahari yang diterima oleh panel surya. Radiasi yang diserap oleh panel surya pada musim kemarau lebih besar dibanding musim hujan. Kita tahu bahwa matahari tidak tertutup awan sehingga indeks kecerahanya lebih besar. Berdasarkan latar belakang tersebut penelitian ini merancang pemanfaatan serta konversi energi surya sebagai sumber energi listrik digunakan untuk mensuplai pompa pada tanaman hidroponik, dengan modul surya jenis Polycristalline pada sudut kemiringan $25-35^{\circ}$.

\section{METODE/PERANCANGAN PENELITIAN}

\subsection{Membuat Perancangan Catu Daya}

Metode yang digunakan penelitian ini meliputi observasi kebutuhan beban listrik dalam hal ini pompa yang digunakan, perancangan teknologi untuk tanaman hidroponik menggunakan energi surya, pembuatan sistem hidroponik, pembuatan sumber energi listrik menggunakan tenaga surya, integrasi hidroponik energi surya, pengujian. Pompa air merupakan suatu komponen yang wajib ada dalam sistem penanaman hidroponik, dikarenakan pada sistem hidroponik air merupakan asupan nutrisi yang utama dalam menghasilkan tanaman yang baik. Pompa air berfungsi untuk menyalurkan air dan nutrisi pada tanaman. Pompa mermelukan catu daya, maka dari itu catu daya yang digunakan bersumber dari tenaga surya yang dikonversi menjadi tenaga listrik. Pada perancangan ini pompa membutuhkan daya 20 Watt.

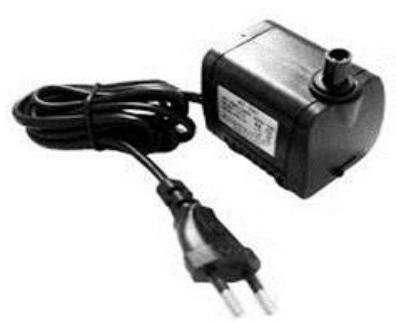

Gambar 1. Pompa Air Hidroponik

Setelah mengetahui kebutuhan beban yang digunakan dilakukan perancangan catu daya atau sumber energi sebagai pembangkit listrik berbasis tenaga surya yang akan digunakan, skema proses pemanfaatan energi tenaga surya ditunjukkan gambar 3 . 


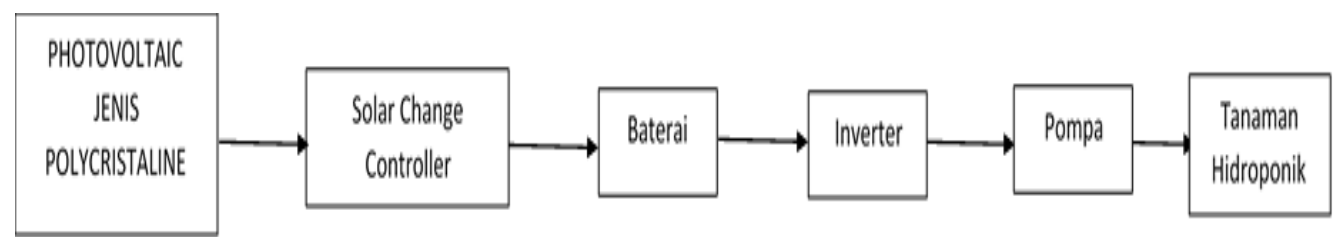

Gambar 2. Skema Pemanfaatan Energi Surya

Modul surya yang tersusun dari beberapa lempeng sel surya selanjutnya dirangkai dalam hubungan seri dan paralel sehingga didapat daya keluaran yang diinginkan, secara umum tegangan terbuka tiap sel surya adalah sekitar 0,6 V, maka untuk menghasilkan tegangan keluaran yang dibutuhkan maka perlu dihubungkan secara seri yang terdiri dari 36 atau 72 lempeng untuk dapat memenuhi sistem $12 \mathrm{~V}$ dan $24 \mathrm{~V}$ [10]. Ada tiga jenis modul surya yang dapat digunakan yaitu thin film, monocrystalline dan polycrystalline [11]. Pada penelitian ini menggunakan modul surya jenis polycrystalline.

\subsection{Pengujian Catu Daya}

Skema rancangan penelitian dilanjutkan dengan pengujian komponen-komponen yang digunakan, seperti yang dapat digambarkan pada gambar 3 .

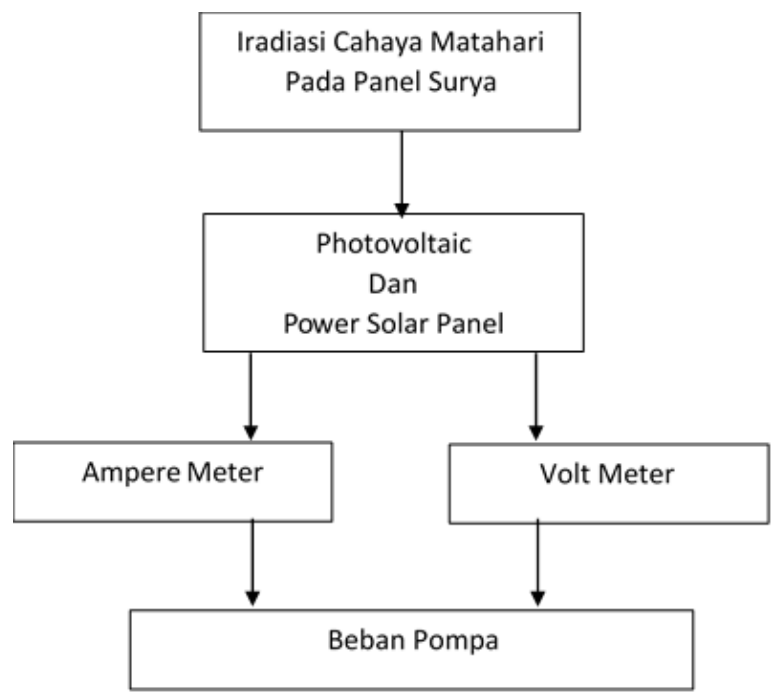

Gambar 3. Skema Pengujian Sistem

Data didapat dengan melakukan pengukuran besar tegangan serta arus keluaran pada panel surya. Untuk mengetahui besarnya nilai daya yang diperoleh, maka perlu mengetahui besar daya yang diperoleh, merupakan perkalian antara intensitas radiasi matahari yang diterima dengan luas area modul PV dengan persamaan [10]:

$$
\operatorname{Pin}=\operatorname{Ir} \times A
$$

Keterangan:

$$
\begin{aligned}
& \text { Pin } \quad \text { Daya masukan (Watt) } \\
& \text { Ir } \quad=\text { Intensitas radiasi matahari }\left(\text { Watt } / \mathrm{m}^{2}\right) \\
& \mathrm{A}=\text { Luas area permukaan panel }\left(\mathrm{m}^{2}\right)
\end{aligned}
$$




\section{Energi dan Kelistrikan: Jurnal Ilmiah}

Vol. 13, No. 1, Januari - Juni 2021, P-ISSN 1979-0783, E-ISSN 2655-5042

https://doi.org/10.33322/energi.v13i1.984

Modul surya yang digunakan dalam perancangan catu daya untuk tanaman hidroponik memiliki spesifikasi seperti yang ditunjukkan tabel 1 .

Tabel 1. Spesifikasi Modul Surya

\begin{tabular}{|c|c|c|}
\hline Maximum Power & Pmax & $50 \mathrm{~W}$ \\
\hline Maximum Power Voltage & Vm & $17.6 \mathrm{~V}$ \\
\hline Maximum Power Current & Imp & $2.85 \mathrm{~A}$ \\
\hline Open Circuit Voltage & Voc & $22.5 \mathrm{~V}$ \\
\hline Short Circuit Current & Isc & $3.04 \mathrm{~A}$ \\
\hline Nominal Operating Cell Temp & NOCT & $45 \pm 2^{\circ} \mathrm{C}$ \\
\hline Maximum System Voltage & & $1000 \mathrm{~V}$ \\
\hline Maximum Series Fuse & & $15 \mathrm{~A}$ \\
\hline ICA Solar Polycrystalline
\end{tabular}

\section{HASIL DAN PEMBAHASAN}

Sel surya merupakan komponen piranti elektronika yang mengkonversi energi matahari menjadi energi listrik dalam bentuk arus searah (DC). Piranti modul surya (fotovoltaic) ialah sejumlah sel surya yang dirangkai baik seri maupun paralel digunakan agar dapat meningkatkan tegangan serta arus yang dihasilkan sehingga dapat dimanfatkan pada sistem catu daya beban. Agar memperoleh output energi listrik secara maksimum maka permukaan modul harus selalu mengarah ke matahari. Seperti kita ketahui Indonesia merupakan negara tropis dengan paparan radiasi matahari yang cukup baik, untuk mendapatkan paparan radiasi yang baik maka peletakan pembangkit listrik dengan energi surya harus disesuaikan dengan sudut yang sudah ditentukan. Hal tersebut tentunya lokasi menjadi salah satu komponen yang perlu diperhatikan saat survei lokasi. Selanjutnya energi yang didapat harus disimpan agar tidak habis, baterai merupakan alat penyimpan energi sekaligus alat pengatur elektronik atau sering kita kenal dengan istilah Charger Regulator. Komponen tersebut juga berfungsi sebagai pengatur tegangan baik dalam keadaan maksimul maupun minimum, serta pengaman saat terjadi arus yang berlebih yang disebabkan pemakaian oleh beban. Tentunya dengan adanya charger regulator dapat meminimalisir arus balik yang mungkin timbul pada mudul surya, juga melindungi saat terjadi hubung singkat dengan komponen yang ada.

\subsection{Hasil Pengujian dan Pengukuran}

Pada perancangan yang dibangun pada penelitian ini terdiri dari komponen hidroponik dan komponen catu daya yang bersumber energi tenaga surya, rancangan yang dibangun ditunjukkan gambar 4.
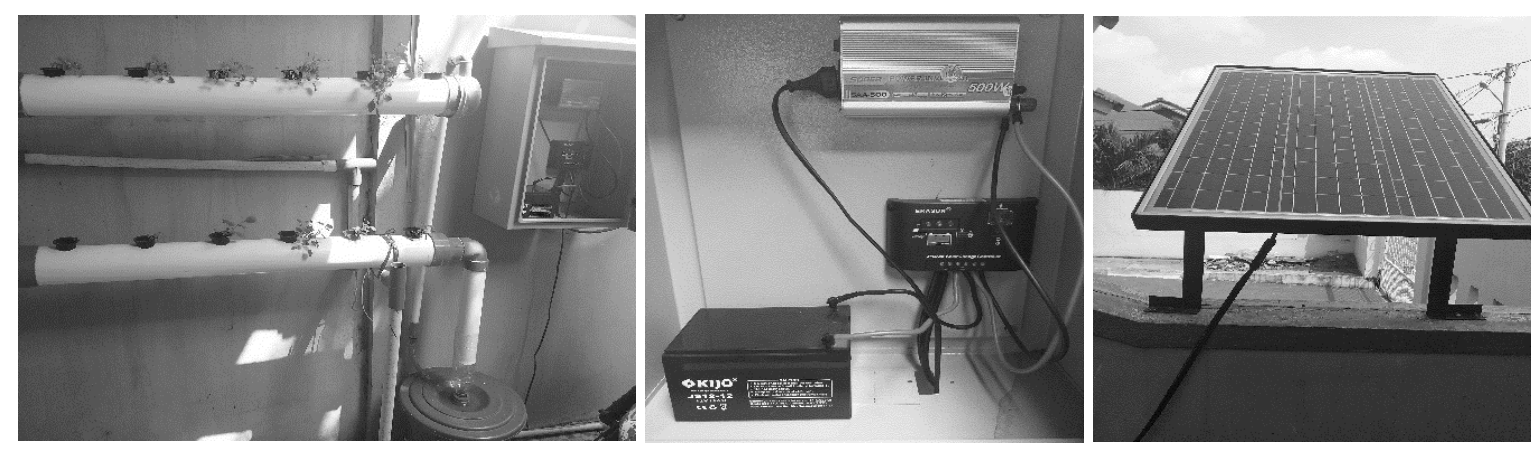

Gambar 4. Perancangan Hidroponik dengan Catu Daya Energi Tenaga Surya 
Dalam penelitian pemanfaatan energi listrik tenaga surya jenis polycristaline sebagai catu daya pada tanaman hidroponik, dengan menggunakan energi matahari sebagai sumber energi terbarukan lalu dikonversi menjadi energi listrik (photovoltaic) yang digunakan untuk pompa air yang berfungsi menyalurkan air ke tanaman hidroponik. Akan tetapi sebelum dihubungkan ke pompa air, energi matahari yang telah dirubah menjadi energi listrik selanjutnya harus dikonversi dahulu ke listrik AC dengan menggunakan alat yang dinamakan inverter. Pada penelitian ini kita menggunakan sudut kemiringan $35^{\circ}$. Penempatan sudut juga berpengaruh pada hasil atau besar luaran energi yang dihasilkan oleh PLTS, hasil iradiasi cahaya matahri pada panel surya ditunjukkan gambar 5 .

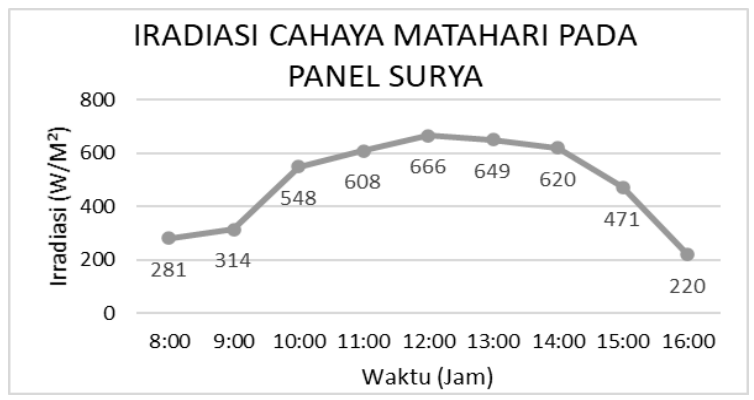

Gambar 5 . Grafik Pengukuran Iradiasi Matahari Pada Panel Surya

Berdasarkan gambar 5. Pengukuran iradiasi pengujian cahaya matahari terhadap panel surya, iradiasi tertinggi pada pukul 12.00 sebesar $666 \mathrm{~W} / \mathrm{M}^{2}$ yang berarti pada waktu tersebut energi yang dihasilkan maksimal. Hasil grafik tersebut memberikan korelasi antara intensitas cahaya matahari pada daya keluaran yang diperoleh pada sel surya, daya keluaran didapat dari perkalian antara tegangan dan arus pada data yang didapat. Pada grafik diatas menunjukan bahwa iradiasi mencapai nilai yang tinggi pada saat jam 12:00 - 14:00, untuk nilai arus keluaran juga mencapai nilai yang tinggi pada saat jam 12:00 - 14:00. Berbeda dengan nilai tegangan yang konstan yaitu $12 \mathrm{~V}, 12 \mathrm{Ah}$ maka energi yang tersimpan di batterai adalah $144 \mathrm{Wh}$ berdasarkan dari persamaan 2 . Dengan hal ini daya keluaran juga bernilai tinggi sama halnya dengan arus dan iradiasi yaitu pada saat jam 12:00 - 14:00. Hasil iradiasi maksimum pada jam 12:00, maka daya yang dihasilkan juga maksimum. Daya total didapat dari penjumlahan semua daya persamaan 2.

Kebutuhan baterai : $\mathrm{P}=\mathrm{V} \times \mathrm{I}$

$$
\mathrm{P}=12 \mathrm{~V} \times 12 \mathrm{Ah}=144 \mathrm{Wh}
$$

Intensitas (iradiasi) matahari dapat mempengaruhi kualitas daya, jika intensitas cahaya tidak maksimal maka daya yang dihasilkan juga tidak maksimal begitu pula berlaku untuk sebaliknya. Penggunaan sudut pada panel surya juga dapat mepengaruhi hasil iradiasi yang diterima. Selain itu faktor kebersihan pada panel juga mempengaruhi iradiasi yang diterima oleh panel surya, jika permukaan berdebu maka akan mengurangi intensitas radiasi yang masuk.

Pada pengujian pompa untuk mengalirkan air dan larutan nutrisi melalui pipa atau pot yang berisi akar-akar tanaman. Air dan larutan bersirkulasi secara konstan selama 24 jam atau diatur pada saat tertentu agar dapat mengalir. Sebagian akar tanaman yang terendam dalam larutan nutrisi tersebut, sebagian lagi berada di atas permukaan larutan, agar tanaman tetap terjaga air dan nutrisinya. Hasil pengujian pompa di dapat besar daya keluaran 20W dengan ketinggian maksimum tekanan Air 1.6 m serta debit Air yang mengalir pada pipa hidroponik 1000 L/H. Pengujian pompa 


\section{Energi dan Kelistrikan: Jurnal Ilmiah}

Vol. 13, No. 1, Januari - Juni 2021, P-ISSN 1979-0783, E-ISSN 2655-5042

https://doi.org/10.33322/energi.v13i1.984

bertujuan mengetahui berapa besar kapasitas yang dibutuhkan agar catu daya dengan menggunakan PLTS mampu mensuplai daya pada pompa, gambar pengujian pompa ditunjukkan gambar 6 .

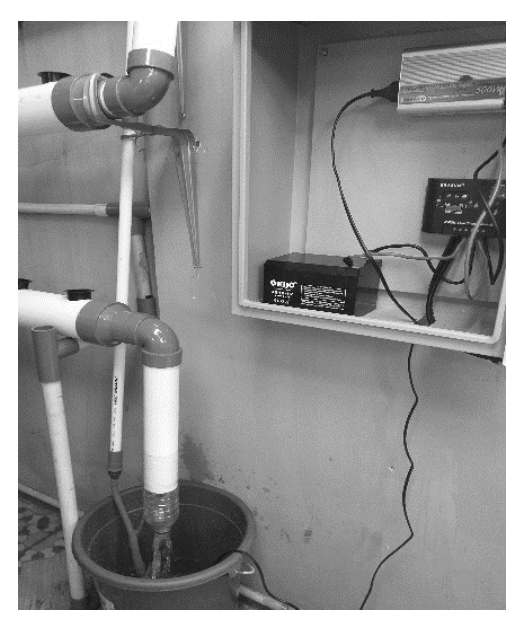

Gambar 6. Pengujian Pompa

\subsection{Analisis Pemanfaatan Energi Surya Untuk Catu Daya}

Untuk kebutuhan beban atau energi listrik yang digunakan untuk menghidupkan pompa ditunjukkan pada tabel 2.

Tabel 2. Kebutuhan Beban Listrik

\begin{tabular}{|c|c|c|c|c|}
\hline No & Keterangan & Jumah & Watt & Total \\
\hline 1 & Pompa (20W 24 Jam) & 1 & 480 & 480 \\
\hline Subtotal 1 & & & 480 \\
\hline Cadangan 30\% & & & 144 \\
\hline Subtotal 2 & & & 624 \\
\hline Rugi rugi sistem 30\% & & & 187 \\
\hline Total Keseluruhan & & & 811 \\
\hline
\end{tabular}

Tabel 2. menunjukkan pada beban yang digunakan hanya pompa listrik sebesar 20 watt, dapat disimpulkan bahwa Total kebutuhan energi listrik paling besar adalah sebesar $811 \mathrm{Wh} / \mathrm{hari}$ termasuk cadangan energi listrik 30\% dan rugi-rugi sistem 30\% efisiensi $70 \%$. Sedangkan total kebutuhan energi listrik paling kecil adalah sebesar $480 \mathrm{Wh} / \mathrm{hari}$, jika tidak memperhitungkan cadangan energi listrik 30\% dan rugi-rugi sistem $30 \%$.

$$
\begin{array}{lll}
\text { Beban }(\text { Pompa }) & =20 \mathrm{Watt} \times 24 \mathrm{Jam} & =480 \mathrm{Watt} \\
\text { Cadangan } & =30 \% \mathrm{x} 480 \mathrm{Watt} & =144 \mathrm{Watt} \\
\text { Sub Total } & =480 \mathrm{Watt}+144 \mathrm{Watt} & =624 \mathrm{Watt} \\
\text { Rugi-rugi sistem } & =624 \mathrm{Watt} \times 30 \% & =187 \mathrm{Watt} \\
\text { Total Keseluruhan } & =480 \mathrm{Watt}+144 \mathrm{Watt}+624 \mathrm{Watt}+187 \mathrm{Watt} \\
& =811 \mathrm{Watt}
\end{array}
$$

Total suplai kebutuhan pompa akan bertahan $(12$ Ah x 12 Watt x 0,8)/(20 Watt $)=5-6$ jam 
Energi listrik yang dapat tersimpang dan di manfatkan untuk kebutuhan pompa dapat bertahan selama 5 - 6 jam saja dengan menggunakan sumber dari PLTS itu sendiri, dimana 0,8 (80\%) merupakan DOD (Depth of Discharge) pada battery.

Dari perancangan yang telah dilakukan sistem yang dibangun mampu berfungsi secara baik. Uji coba dilakukan di Tangerang pada pukul 08.00-16.00 WIB. Hasil dari ujicoba lapangan menunjukan bahwa alat dapat bekerja menghidupkan pompa air melalui inverter yang dicatu oleh batterei dan panel surya. Dikarena pada perancangan ini menggunakan jenis baterai industrial lead acid, merupakan jenis yang banyak digunakan. Baterai jenis ini dengan memanfaatkan Asam Timbal (Lead Acid) sebagai bahan kimianya. Dalam penggunaannya, tipe baterai ini memiliki batas ideal $80 \%$. Hal ini berarti dari daya baterai $100 \%$, hanya maksimal $80 \%$ daya yang dapat digunakan. Penelitian ini menggunakan tipe baterai VRLA Deep Cycle JS12-12; 12V 12Ah, yang berarti dengan kapasitas baterai yang tersedia belum bisa digunakan selama $24 \mathrm{jam}$. Oleh sebab itu dari perancangan yang sudah dikakukan jika tenaga batterei sudah hampir habis (low) maka sumber energi dapat dialihkan ke sumber energi dari PLN sehingga pompa masih tetap bekerja. Tentunya dengan pemanfaatan energi tersebut dapat mengurangi konsumsi energi listrik serta menghemat biaya yang dikeluarkan.

\section{KESIMPULAN DAN SARAN}

Dari pengujian dan perancangan yang dilakukan semua sistem dapat bekerja dengan baik. Konversi energi listrik dengan memanfaatkan sumber energi matahari dapat menghidupkan pompa air pada tanaman hidroponik, dengan beban yang digunakan hanya pompa listrik sebesar 20 watt, dapat disimpulkan bahwa Total kebutuhan energi listrik adalah sebesar $480 \mathrm{Wh} / \mathrm{hari}$, namun jika memperhitungkan cadangan energi listrik 30\% dan rugi-rugi sistem 30\%. DOD (Depth of Discharge) pada battery bernilai $80 \%$ atau $(0,8)$ maka PLTS hanya dapat menyuplai beban selama $5-6$ jam. Untuk itu maka perlu dibutuhkan penambahan kapasitas battery atau mengurangi penggunaan daya pada pompa agar dapat menyuplai beban selama 24 jam. Adanya faktor perubahan cuaca atau kendala lainya juga dapat mempengaruhi hasil daya output karena akan berpengaruh terhadap iradiasi yang diterima oleh panel surya.

\section{UCAPAN TERIMA KASIH}

Penulis berterima kasih sebanyak-banyak nya kepada Institut Teknologi PLN serta LPPM yang telah mendanai penelitian ini sehingga kegiatan dapat berjalan sebagaimana mestinya. Tak lupa juga kepada tim peneliti.

\section{DAFTAR PUSTAKA}

[1] M. Bachtiar, "Prosedur Perancangan Sistem Pembangkit Listrik Tenaga Surya Untuk Perumahan (Solar Home System),” SMARTek, no. 3 vol. 4 , pp. 176-182, 2006.

[2] Samsurizal, A. Makkulau dan Christiono, "Analisis Pengaruh Sudut Kemiringan Terhadap Arus Keluaran Pada Photovoltaic Dengan Menggunakan Regretion Quadratic Method," Energi dan Kelistrikan, no. 2. vol.10 , pp. 137-144, 2018.

[3] L. Melvix dan C. Sridevi, "Design of Efficient Hydroponic Nutrient Solution Control System using Soft Computing based Solution Grading," dalam International Conference on Computation of Power, Energy, Information and Communication (TCCPETC), 2014.

[4] R. Rosliani dan N. Sumarni, Budidaya Tanaman Sayuran dengan Sistem Hidroponik. Bandung: Balai Penelitian Tanaman Sayuran., Bandung: Balai Penelitian Tanaman dan Sayuran, 2005. 


\section{Energi dan Kelistrikan: Jurnal Ilmiah}

Vol. 13, No. 1, Januari - Juni 2021, P-ISSN 1979-0783, E-ISSN 2655-5042

https://doi.org/10.33322/energi.v13i1.984

[5] A. V dan e. all, "Automatic control of drip irrigation on hydroponic agriculture," IEEE International Conference on Automatica (ICA-ACCA)(IEEE), no. Daniela tomato production, p. 16, 2016.

[6] J. Jatmiko, "Pemanfaatan sel surya dan lampu LED untuk perumahan," Semantik, no. 1 vol.1, 2011.

[7] Samsurizal, Christiono dan A. Makkulau, "Evaluasi Sudut Kemiringan Terhadap Pengaruh Irradiance Pada Array Photovoltaic Jenis Monocristalline," Jurnal SETRUM, no. 1. vol.8 , pp. 28-34, 2019.

[8] A. Makkulau, Christiono dan Samsurizal, "Characteristics of Temperature Changes Measurement on Photovoltaic Surfaces Against Quality of Output Current on Solar Power Plants," International Conference on Technologies and Policies in Electric Power \& Energy, IEEE, vol. doi: 10.1109/IEEECONF48524.2019.9102630., pp. 1-4, 2019.

[9] B. Delya dan e. all, "Rancang Bangun Sistem Hidroponik Pasang Surut Otomatis Untuk Budidaya Tanaman Cabai,” Jurnal Teknik Pertanian Lampung, no. 3. vol.3 , pp. pp. 205-215, 2014.

[10] A. W. W. A. B. Duffie, Solar Engineering Of Thermal Processes, Newyork: John Wiley \& Sons, 2008.

[11] APAMSI, Pengembangan PLTS di Indonesia, Yogyakarta, 2013.

[12] FU, Ran; Feldman, David J.; Margolis, Robert M. US solar photovoltaic system cost benchmark: Q1 2018. National Renewable Energy Lab.(NREL), Golden, CO (United States), 2018.

[13] Seyedmahmoudian, Mehdi, et al. Efficient photovoltaic system maximum power point tracking using a new technique. Energies, 9.3: 147, 2016.

[14] KulkarnI, Sambhaji, et al. Automation of Hidroponic System. International Journal Of Science Technology \& Engineering, 3.9, 2017.

[15] DIAS, Pablo Ribeiro; BENEVIT, Mariana Gonçalves; VEIT, Hugo Marcelo. Photovoltaic solar panels of crystalline silicon: Characterization and separation. Waste Management \& Research, 34.3: 235-245, 2016.

[16 ] XU, Yan, et al. Global status of recycling waste solar panels: A review. Waste Management, 75: 450-458, 2018. 